\title{
Kinematics of Spruce Creek rock glacier, Colorado, USA
}

\author{
Eric M. LEONARD, ${ }^{1}$ Peter STAAB, ${ }^{2 *}$ Stephen G. WEAVER ${ }^{1}$ \\ ${ }^{1}$ Department of Geology, Colorado College, Colorado Springs, Colorado 80903, USA \\ E-mail: eleonard@coloradocollege.edu \\ ${ }^{2}$ Department of Mathematics, Colorado College, Colorado Springs, Colorado 80903, USA
}

\begin{abstract}
A 14 year kinematic survey of Spruce Creek rock glacier, Colorado, USA, provides information on rates and controls of surface strain. Steel-tape measurements of differential movement yield data of $\mathbf{c m}$-scale accuracy, sufficient to assess strain patterns over small portions of the very slowly deforming rock glacier. Flow rates are typically $<10 \mathrm{~cm} \mathrm{a}^{-1}$, and measured strain rates range from $1.0 \times 10^{-5} \mathrm{a}^{-1}$ to $1.5 \times 10^{-3} \mathrm{a}^{-1}$. The primary control on longitudinal strain is changing surface slope, with extending flow occurring in areas of down-valley increase in slope, and compressing flow in areas of down-valley slope decrease. Relatively high strain rates are associated with higher flow velocities and with the impingement of faster-flowing up-valley portions of the rock glacier on the slower-moving lower portion. Overall strain rates decreased through the study period, probably as a result of a slowing of the upper part of the rock glacier. Transverse ridges are associated with longitudinal shortening, caused by either slope changes or impingement of faster-moving sections of the rock glacier on slowermoving sections, but transverse ridges do not occur in every area of strong longitudinal shortening.
\end{abstract}

\section{INTRODUCTION}

During the last several decades, the kinematics of ice glaciers has been studied intensively. This work has involved formulation of a flow law for glacier ice, assessment of strain patterns on glaciers, and development of an understanding of relationships between these patterns and dynamic controls related to glacier mass balance and geometry (Paterson, 1994). In recent years, understanding of rock glacier kinematics has also progressed, as a result of borehole, laboratory and surface studies, particularly in the Alps, but it continues to lag behind our knowledge of ice glaciers. We currently lack a clear understanding of the constitutive relationship for rock glacier material. Understanding of patterns of surface strain in rock glaciers and explanation of these patterns in terms of mass balance, geometry, surface morphology and flow characteristics is also incomplete. Our less developed understanding of rock glacier deformation reflects several factors. Because they are complexly structured mixes of ice and rock, it is to be expected that rock glaciers will have complex and diverse flow characteristics. Additionally, there are many impediments to detailed study of rock glacier deformation, including difficulties of coring, of conducting laboratory experiments on heterogeneous ice-debris mixtures, and of making accurate and representative measurements of small differential movements of typically unstable surface materials.

In this paper, we present data from a 14 year (1985-99) survey of surface strain and its relationship to rock glacier morphology at Spruce Creek rock glacier, in the Ten Mile Range of the Colorado Rockies, USA. The work was conducted as part of a broader project on rock glacier flow, which also examined flow velocities over interannual to millennial time-scales. We utilized simple but precise steeltape measurements to assess strain.

*Present address: Department of Mathematics, Tufts University, Medford, Massachusetts 02155, USA.

\section{PREVIOUS WORK ON ROCK GLACIER KINEMATICS}

Since the pioneering work of Wahrhaftig and Cox (1959), many workers have examined rock glacier surface flow velocities, using field-survey (e.g. White, 1971; Potter, 1972; Benedict and others, 1986; Konrad and others, 1999), photogrammetric (e.g. Messerli and Zurbuchen, 1968; Barsch and Hell, 1975; Haeberli and others, 1979; Kääb and others, 1997, 1998, 2002; Frauenfelder and Kääb, 2000; Kaufmann and Ladstädter, 2003) or synthetic aperture radar (SAR) methods (Rignot and others, 2002; Kenyi and Kaufmann, 2003). Subsurface deformation has been examined in several borehole studies (Johnson and Nickling, 1979; Wagner, 1992; Hoelzle and others, 1998; Arenson and others, 2002, 2003a), and rock glacier material has been deformed experimentally in the laboratory (Arenson and others, 2003b). A few studies have examined surface strain in detail, assessing strain either related to particular surface features by making repeated steel-tape measurements (Potter, 1972; White, 1987) or by photogrammetry. Haeberli and others (1979) used photogrammetry to assess strain rates at Gruben rock glacier, Swiss Alps, and Kääb and his coworkers (Kääb and others, 1997, 1998; Kääb and Vollmer, 2000) continued and refined this approach, using highprecision photogrammetry to determine principal strain axis orientations and strain rates at several Swiss rock glaciers.

\section{FIELD AREA}

Spruce Creek rock glacier is located on the eastern flank of the Ten Mile Range of Colorado (Fig. 1). It is fed by rockfall from the back- and side-walls of the northeast cirque of $4252 \mathrm{~m}$ Pacific Peak (Fig. 2). The back wall rises steeply $250 \mathrm{~m}$ from talus at the head of the rock glacier to the peak. Bedrock is almost exclusively Proterozoic high-grade metamorphic rock, primarily biotitic gneiss (Tweto, 1974), with pegmatite and other dike rocks present in low abundance. Rock glacier surface material is overwhelmingly coarse, angular gneiss. Clasts several meters in diameter are common. The rock glacier surface is generally nonvegetated, except for sparse lichen cover. 


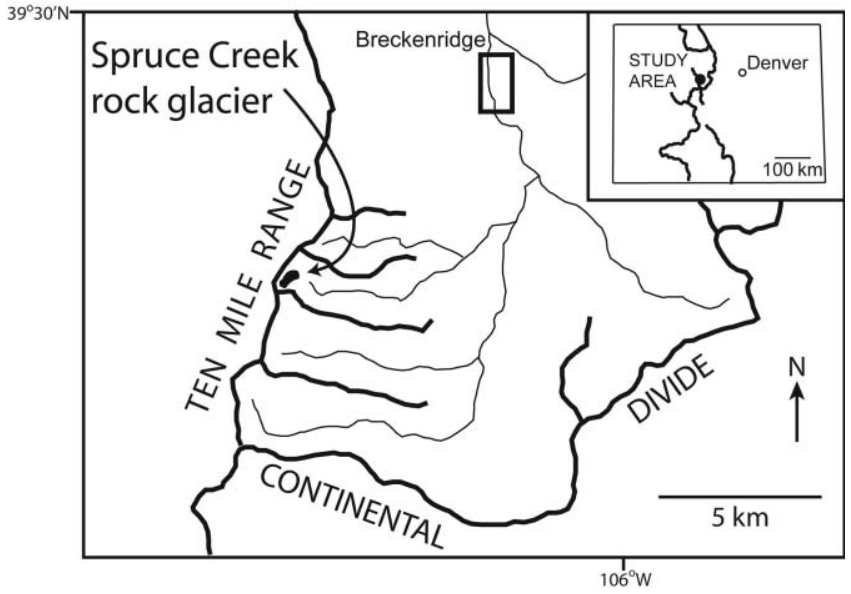

Fig. 1. Location map. Heavy lines are drainage divides; light lines are streams. Insert maps shows the state of Colorado. Lines on insert map are crests of mountain ranges.

No meteorological data are available for the Spruce Creek valley. The nearest station with continuous records is Climax, Colorado (Western Regional Climate Center, http:// www.wrcc.dri.edu/cgi-bin/cliMAIN.pl?coclim), $8-9 \mathrm{~km}$ to the southwest at $3460 \mathrm{ma}$ a.s.l. Combining data from this station with regional annual and summer lapse rates of approximately $0.62^{\circ} \mathrm{C}(100 \mathrm{~m})^{-1}$ and $0.73^{\circ} \mathrm{C}(100 \mathrm{~m})^{-1}$ respectively (Leonard, unpublished information) indicates annual and July mean temperatures at the rock glacier of about $-4^{\circ} \mathrm{C}$ and $7^{\circ} \mathrm{C}$ respectively. No data are available on ground temperatures at the rock glacier.

\section{ROCK GLACIER MORPHOLOGY}

The rock glacier extends about $700 \mathrm{~m}$ down-valley, from its head in steep talus and semi-permanent snowfields at $\sim 4000$ m a.s.l., to a terminus at $\sim 3870$ ma.s.l. Its width ranges from about $200 \mathrm{~m}$ in its upper portion to $280 \mathrm{~m}$ near the terminus. Surface slope of the uppermost $150 \mathrm{~m}$ of the rock glacier, where it grades into talus, averages about $15^{\circ}$. The slope of the lower $550 \mathrm{~m}$ of the rock glacier averages $5.9^{\circ}$, but varies along two gentle rolls evident in a center-line longitudinal profile (Fig. 3). At the terminus, there is a sharp break between the top and frontal slopes. The $40-45 \mathrm{~m}$ high frontal slope ranges from $40^{\circ}$ to $46^{\circ}$, excluding a basal talus apron, closely comparable to slopes on active rock glacier fronts in the Colorado Front Range (White, 1971).

Surface morphology of the rock glacier suggests that its upper portion consists of two lobes that are impinging upon the lower portion (Figs 2 and 3). The down-glacier margin of each lobe is a steep, 3-6 m high, down-glacier-facing scarp that is convex down-glacier. A sharp gradient in lichen size occurs across each scarp, suggesting abrupt down-glacier increases in surface age or stability (Leonard and others, unpublished information). As will be discussed below, measured flow velocities are higher up-glacier from the scarps than down-glacier, further supporting the suggestion that more active, up-glacier lobes are impinging upon less active material down-glacier.

Ridge and furrow topography is well developed on some parts of the rock glacier. Transverse ridges are best developed where the upper portion of the rock glacier impinges on the lower. Longitudinal ridges are developed along both sides of

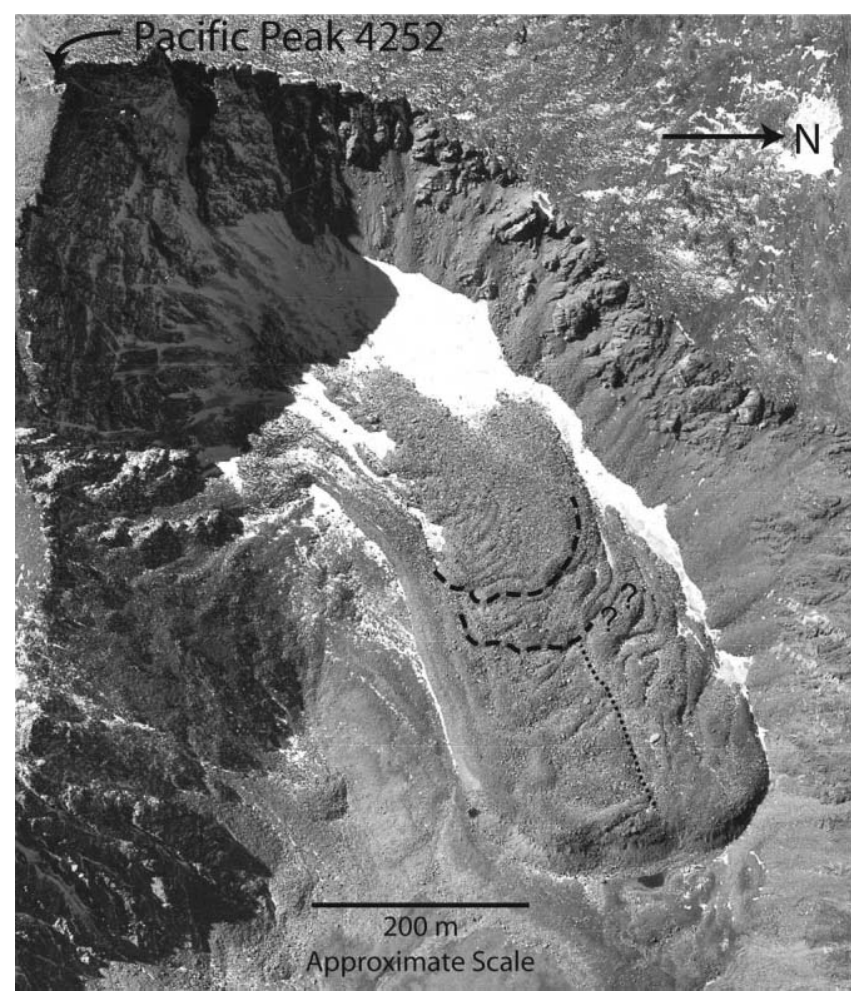

Fig. 2. Spruce Creek rock glacier. Dashed lines indicate the downvalley extents of two lobes impinging on the lower portion of the rock glacier. Dotted line indicates the position of the pronounced longitudinal furrow in the lower portion of the rock glacier. Photograph by US Department of Agriculture Forest Service, taken on 3 October 1972.

the rock glacier, particularly the southern (right) margin. A well-developed longitudinal furrow bisects the lower portion of the rock glacier (Fig. 2). Patterns of transverse ridges are not continuous across this furrow, and there is some indication in velocity measurements that the two sides of the rock glacier may move somewhat independently of one another across the furrow (Leonard, unpublished information).

Many aspects of the morphology of the rock glacier, particularly its steep frontal slope, surface and frontal instability and lack of vegetation cover, suggest that it is active at present. As is discussed below, however, measured flow velocities and strain rates are quite low.

\section{STUDY AIMS}

The principal aims of this study were to assess patterns and variations in surface strain on Spruce Creek rock glacier and to relate these patterns to the rock glacier morphology. We hoped to document the relationship of surface strain to position on rock glacier, changes in slope, transverse ridges and impinging up-glacier lobes.

\section{METHODOLOGY}

Measured strain rates at Spruce Creek rock glacier (discussed below) are typically on the order of $10^{-4} \mathrm{a}^{-1}$. To examine strain patterns related to rock glacier morphology, it was necessary to measure differential movements over distances of no more than a few tens of meters. Thus, we needed to measure accurately differential movements of only a few $\mathrm{mm} \mathrm{a}^{-1}$. Even if strain were measured over several-year time 


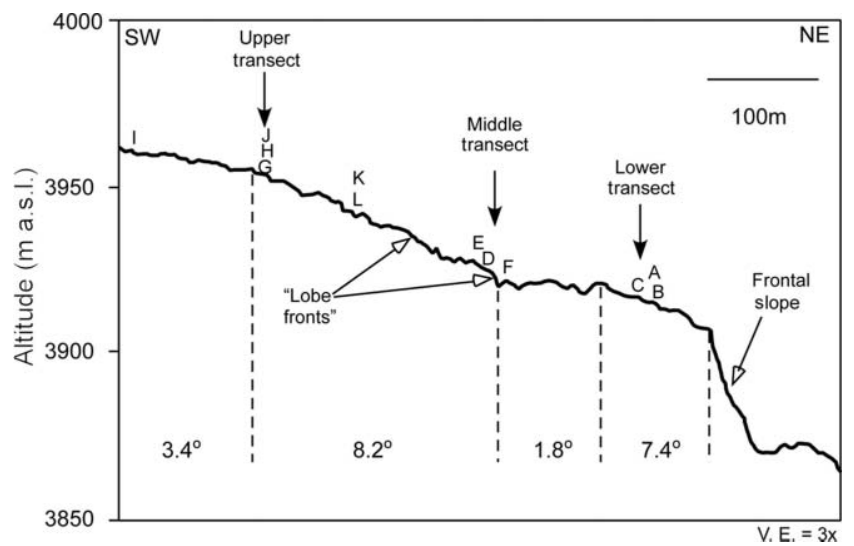

Fig. 3. Center-line longitudinal profile of the lower $550 \mathrm{~m}$ of Spruce Creek rock glacier. Solid arrows indicate the position of surveyed cross-rock-glacier velocity transects; open arrows indicate major morphological features of the rock glacier surface. Letters show the approximate positions of strain diamonds projected to the center line, and dashed lines and angles indicate changes in surface slope of the rock glacier. Profile was produced photogrammetrically.

intervals, cm-scale accuracy was necessary. Of the two methods previously utilized in strain analysis of rock glaciers, only steel-tape measurements are capable of cmscale accuracy (White, 1987). Photogrammetric methods are capable of only decimeter-scale accuracy (Kääb and others, 1997), too coarse to document strain over short distances on a very slowly deforming feature. In recent years, development of total station survey instruments and SAR has made available additional means of assessing differential movement at cm-scale accuracy, possibly $\mathrm{mm}$ scale under optimal conditions with SAR (Rignot and others, 2002). These methods were not available at the time of initiation of this study, and while future studies of low-strain-rate rock glaciers will undoubtedly make use of these methods, they do not yet offer data of the time depth of the current steeltape study.

\section{Field methods}

Nye (1959) proposed using steel-tape measurements to evaluate strain on ice glaciers and we used a modified version of his method. Nye's method involved placing five stakes in the ice, four in a square, or 'strain-diamond', pattern with the diagonals of the diamond parallel and perpendicular to ice-flow direction. The fifth stake was located in the center of the diamond. Repeat steel-tape distance measurements between the stakes provided eight independent measures of linear strain from which the strain tensor was calculated. In theory, the tensor could be calculated from three non-parallel measurements, but this would yield reliable results only if strain were homogeneous over the area measured. The five additional measurements allowed Nye to average data to reduce the effect of nonhomogeneity. In this study, marked boulders were used in the place of Nye's stakes. Unevenness of the rock glacier surface and the necessity of having clear lines of sight between the marked boulders in each diamond made it very difficult to arrange the diamonds with the ideal configuration outlined by Nye. Because the layout of many of the diamonds differed markedly from the ideal geometry, we needed to develop an alternative method of solving for principal strain orientations and magnitudes, and for

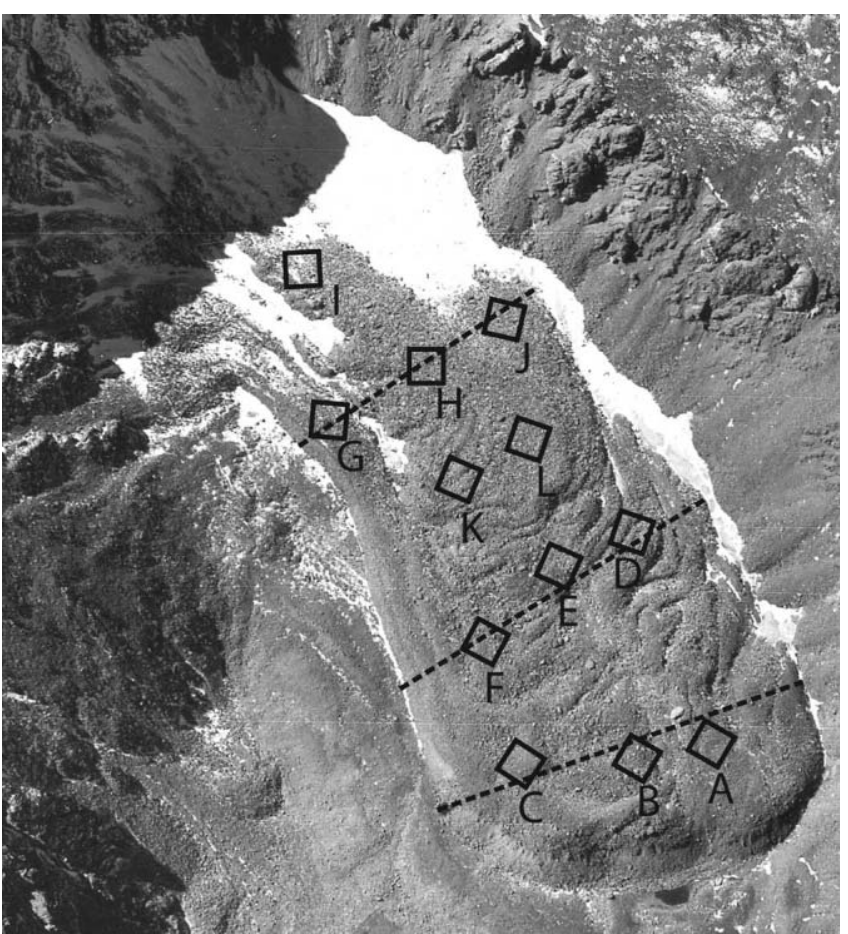

Fig. 4. Location of strain diamonds and velocity transects. Strain diamonds are indicated with idealized geometry but accurate center position.

establishing confidence intervals for these solutions, to that used by Nye. Our method is discussed below.

Strain diamonds were established at 12 sites on the rock glacier (Fig. 4). Nine diamonds (A, B, C, D, E, F, G, H, J) were located along three surveyed velocity transects to allow comparison of strain and velocity data. In addition, three diamonds ( $\mathrm{I}, \mathrm{K}$ and $\mathrm{L}$ ) were sited to provide fuller coverage of the rock glacier surface. Two diamonds ( $D$ and $K$ ) were in locations of well-developed transverse ridges and a third (E) in an area of moderately developed ridges.

At all but one location, five boulders were chosen that most closely approximated the geometry specified by Nye (1959). As there was no suitable boulder in the center of diamond $G$, only the four corner points were marked. Sides of the diamonds were approximately $25 \mathrm{~m}$ long, but varied considerably. Each boulder was marked at a high point with a $5 \mathrm{~mm}$ diameter circle of black paint, within a larger circle of brightly colored paint. Distances between marked boulders were measured to the nearest $0.01 \mathrm{ft}(\sim 3 \mathrm{~mm})$ with a Lufkin steel tape during windless or very low-wind intervals. Initial measurements were made in September 1985, with subsequent remeasurements in late boreal summer or early fall of 1987, 1989, 1992, 1996 and 1999. Line-length measurements were converted to strain magnitudes by dividing the change in line length by the original length of a line, and to strain rates, expressed in units of $\mathrm{a}^{-1}$, by dividing by the time interval between measurements.

There are several potential sources of error in our method; some related to the measurements themselves, others to the assumption that the measurements are indicators of strain across each diamond. Potential measurement errors include (1) imprecision of steel-tape readings, (2) error in locating the center of the $5 \mathrm{~mm}$ black mark at each survey point, (3) error due to application of unequal tension on the steel tape, (4) error due to the effect of wind on measurements, 
Table 1. Measured strain rates at Spruce Creek rock glacier, 1985-99

\begin{tabular}{lccc}
\hline Strain rate & $\begin{array}{c}\text { Entire 14 year } \\
\text { record, 1985-99 }\end{array}$ & $\begin{array}{c}\text { Partial record, } \\
1985-92\end{array}$ & $\begin{array}{c}\text { Partial record, } \\
1992-99\end{array}$ \\
& $10^{-4} \mathrm{a}^{-1}$ & $10^{-4} \mathrm{a}^{-1}$ & $10^{-4} \mathrm{a}^{-1}$ \\
\hline Maximum & 14.7 & 18.3 & 13.8 \\
Minimum & 0.1 & 0.1 & 0.0 \\
Mean & $\mathbf{2 . 8} \pm \mathbf{0 . 3}$ & $\mathbf{3 . 2} \pm \mathbf{0 . 4}$ & $\mathbf{2 . 6} \pm \mathbf{0 . 3}$ \\
\hline
\end{tabular}

Notes: Data are for all 93 measured lines. Mean values are given with two standard error uncertainties. Minimum measured strain rates are smaller than measurement uncertainty $\left(\sim \pm 0.35 \times 10^{-4} \mathrm{a}^{-1}\right.$ for the entire record, $\sim \pm 0.7 \times 10^{-4} \mathrm{a}^{-1}$ for the partial records).

and (5) error due to thermal expansion of the tape. Error related to imprecision of steel-tape readings is approximately $\pm 1.5 \mathrm{~mm}$, and that due to locating the center of the mark is probably about the same. Even with different people applying tension to the tape under different (still-to-gentle) wind conditions, measurements were almost always replicable within $0.02 \mathrm{ft}(\sim 6 \mathrm{~mm})$, similar to the replicability of $5 \mathrm{~mm}$ reported by White (1987). Thermal expansion of the tape over a $15-20^{\circ} \mathrm{C}$ temperature range is about $6 \mathrm{~mm}$ for the longest measurements. Pooling these independent terms, measurement error should be $<1 \mathrm{~cm}$.

Use of these measurements as indicators of strain across a diamond introduces additional sources of error. Our basic assumptions are that, over the scale of individual diamonds, the rock glacier deforms homogeneously and that movement of individual clasts is translational and reflects this overall strain field. Each of these assumptions may be incorrect. Strain may be heterogeneous across diamonds, and individual marked clasts may tilt, rotate or slide with respect to the material below. It may be difficult to separate the effects of broadly non-homogeneous strain across a diamond from such movement of individual clasts. To address these uncertainties, we developed a statistical approach that allows us to find best-fit principal strain axis orientations and magnitudes and to assess confidence intervals around those solutions.

Down-valley movement measurements were made along three bedrock-to-bedrock cross-glacier transects at 2-5 year intervals from 1985 to 2000. Each transect consisted of 8-10 marked clasts on the rock glacier surface. Measurements were made initially using an optical transit and subsequently using a total station.

\section{Mathematical methods}

Our statistical approach to assessing strain is based on the fact that a two-dimensional strain tensor for homogeneous strain can be described as an ellipse, with lengths and orientations of the semi-major and semi-minor axes corresponding to the magnitudes and orientations of maximum and minimum principal strains. For homogeneous strain, the magnitudes and orientations of strains in directions other than principal axis directions will also fall on the ellipse. Because surface strain at the rock glacier is almost certainly non-homogeneous, actual strains will deviate from this ideal relationship. Our approach is to find ellipses that best fit the measured strains at each diamond and to calculate confidence intervals for the orientation and magnitude of the ellipse axes.
An ellipse can be written in polar coordinates as

$$
R(\theta)=\sqrt{\frac{1}{\frac{A^{2}}{\cos ^{2}\left(\theta-\theta_{0}\right)}+\frac{B^{2}}{\sin ^{2}\left(\theta-\theta_{0}\right)}}},
$$

where $\theta_{0}$ is the angle the major axis makes with the positive $x$ axis, and $A$ and $B$ are the semi-major and semi-minor axes respectively. The angle $\theta_{0}$ will be reported between $0^{\circ}$ and $180^{\circ}$. Rotating the ellipse by $90^{\circ}$ (shifting $\theta_{0}$ by $90^{\circ}$ in either direction) will switch the major and minor axes. In the current work, we select $\theta_{0}$ such that $A$ corresponds to the major axis and $B$ to the minor axis.

The best-fit ellipse to the data $\left\{R_{i}, \theta_{i}\right\}$ can be found by minimizing the sum of squares total,

$$
\mathrm{SST}=\sum_{i=1}^{n}\left(R_{i}-R\left(\theta_{i}\right)\right)^{2},
$$

where $R\left(\theta_{i}\right)$ is found using Equation (1). SST is the sum of the squares of the radial distance between the datum and the ellipse. The goal is to find the minimum (specifically the absolute or global minimum) of Equation (2). However, since the global minimum is difficult to find for many functions, we seek a local minimum that occurs when

$$
\frac{\partial \mathrm{SST}}{\partial A}=0 \frac{\partial \mathrm{SST}}{\partial B}=0 \frac{\partial \mathrm{SST}}{\partial \theta_{0}}=0 .
$$

Newton's method (Burden and Faires, 2001) is used to solve Equation (3). This technique takes an initial point and, using an iterative formula, converges to a solution to Equation (3). Since a global minimum of Equation (2) is sought, we use 100 random initial points, iterate Newton's method to solve Equation (3), and select the solution among these that produces the smallest value of Equation (2). Although this does not guarantee a global minimum of Equation (2), in this investigation it does produce the desired result. The values of $A, B$ and $\theta_{0}$ that produce this solution are the best-fit estimators and are denoted $\hat{A}, \hat{B}$ and $\hat{\theta}_{0}$. A standard measure of fit of data to a given curve is $r^{2}$, the regression coefficient. The model sum of squares (SSM) is

$$
\mathrm{SSM}=\sum_{i=1}^{n}\left(R_{i}-\bar{R}\right)^{2},
$$

where $\bar{R}$ is the mean of the radii. Using the two sums of squares listed above, the regression coefficient for the ellipse is

$$
r^{2}=1-\frac{\mathrm{SSM}}{\mathrm{SST}}
$$

The calculation of many statistical inferences of $\hat{A}, \hat{B}$ and $\hat{\theta}_{0}$ can be found using a bootstrapping method (Good, 1999). This technique is used instead of standard confidence interval calculations because in the latter an assumption is made concerning the underlying distribution of the data. In this analysis, we make no assumption about character of strain and consequently can make no assumption about the underlying distribution of data. Instead, the actual data are used and are randomly resampled to produce a large number of additional datasets. The desired statistical measure is then calculated from these sets. Below we describe the procedure used in this case to calculate the confidence intervals and hypothesis tests for $\hat{A}, \hat{B}$ and $\hat{\theta}_{0}$.

Starting with a set of data $\left(R_{i}, \theta_{i}\right)$ we generate a large set of additional data using the following Monte Carlo procedure:

1. The best-fit parameters $\hat{A}, \hat{B}$ and $\hat{\theta}_{0}$ are found using the procedure above. 

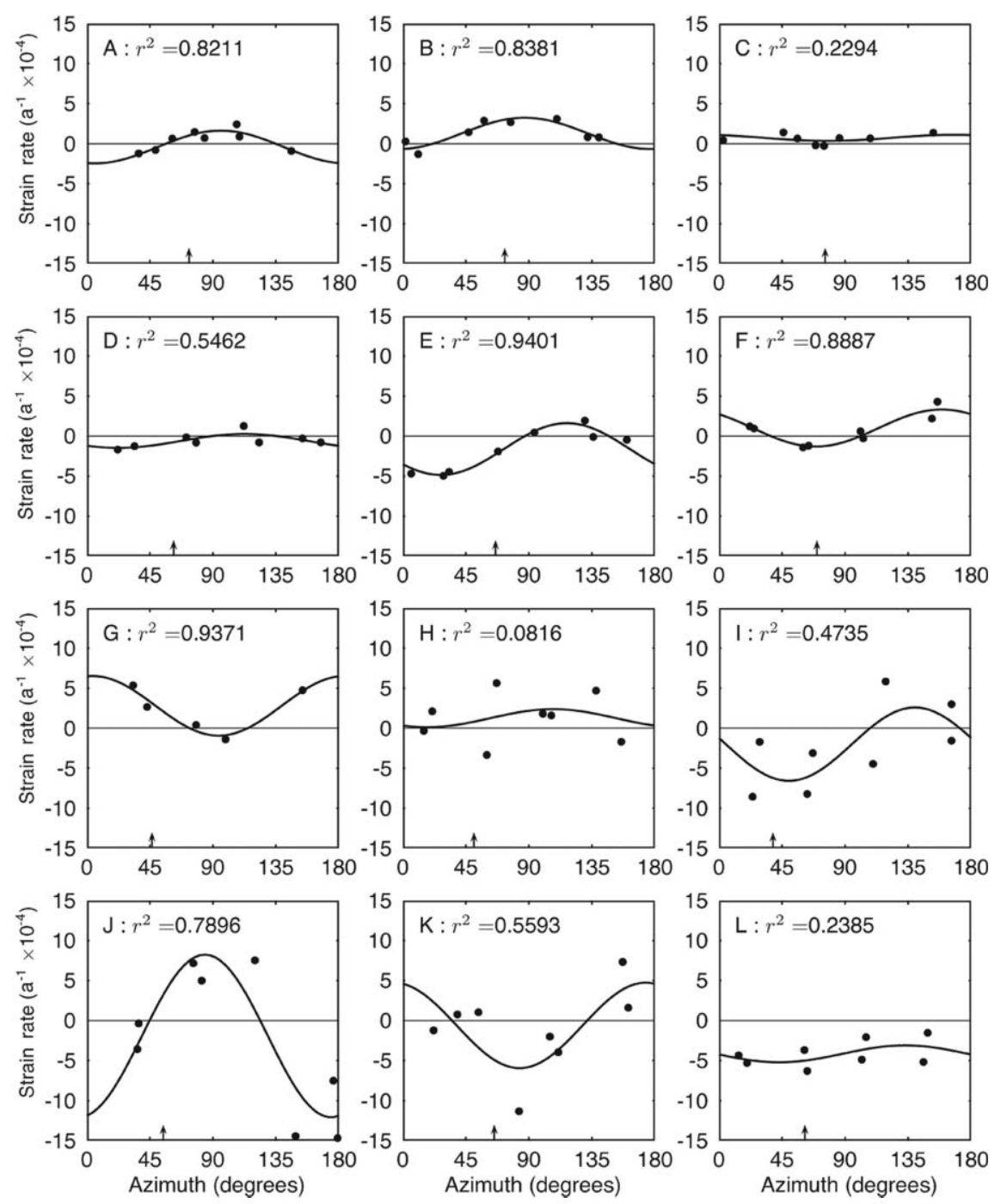

Fig. 5. Plots of orientation and strain rate for all measured lines in all strain diamonds. The curve plotted for each diamond is the statistical best-fit ellipse (see text). The $r^{2}$ value for the fit is given in each plot. The small arrow at the bottom of each plot shows the approximate down-flow direction at that diamond.

2. The residuals, $\varepsilon_{i}=R_{i}-R\left(\theta_{i}\right)$ are calculated for each $i$ in the set. The best-fit estimates are used in the calculation of $R\left(\theta_{i}\right)$ using Equation (1).

3. A new set of data is created using $\left(R_{i}^{*}, \theta_{i}^{*}\right)=$ $\left(R\left(\theta_{i}\right)+e_{j}, \theta_{i}\right)$, where $j$ is chosen randomly from 1 to $n$, the size of the dataset.

4. The best-fit parameters for the ellipse are found for the dataset $\left(R_{i}^{*}, \theta_{i}{ }^{*}\right)$. Again, we use the procedure discussed above.

5. Steps 3 and 4 are repeated $k$ times (we use $k=2000$ ), to generate a distribution of possible values of $\hat{A}, \hat{B}$ and $\hat{\theta}_{0}$. This procedure is executed for each of the 12 strain diamonds. For each diamond, the procedure yields 2000 values for $A$, $B$ and $\theta_{0}$. The $95 \%$ confidence interval is found by taking the 50th and 1950th points in a ranked list of these values.

\section{RESULTS}

Strain was measured along 93 lines in the 12 diamonds. Measured strain rates were highly variable from line to line and over different time intervals along individual lines. Spatially and temporally averaged measured strain rates for the rock glacier are summarized in Table 1. Averaged over the 14 year period of record, measured strain rates ranged by two orders of magnitude, from $1.0 \times 10^{-5} \mathrm{a}^{-1}$ on the most slowly deforming line to nearly $1.5 \times 10^{-3} \mathrm{a}^{-1}$ on the most rapidly deforming line. Minimum measured strain rates were smaller than the uncertainty of about $4 \times 10^{-5} \mathrm{a}^{-1}$ due to potential measurement error. The rock-glacier-wide mean measured strain rate was $(2.8 \pm 0.3) \times 10^{-4} \mathrm{a}^{-1}( \pm$ two standard errors). Measured strain rates (both mean and maximum) decreased by about $20 \%$ between the first 7 years of the survey and the last 7 years.

Best-fit ellipse calculations were made for each strain diamond based on the entire period of survey. Measured differential movement during individual 2-4 year measurement intervals averaged only $1-2 \mathrm{~cm}$, not much greater than the measurement error. When the entire record was used, however, measured differential movement was typically 510 times the error. Results of the best-fit ellipse calculations are shown in Figure 5, which plots strain rate along measured lines as a function of line orientation for each diamond, and shows the calculated best-fit relationships. Table 2 summarizes results of these calculations and the character and rate of longitudinal (flow-parallel) strain. 
Table 2. Calculated principal strain axis orientation and magnitudes. Numbers in parentheses are $95 \%$ certainty ranges

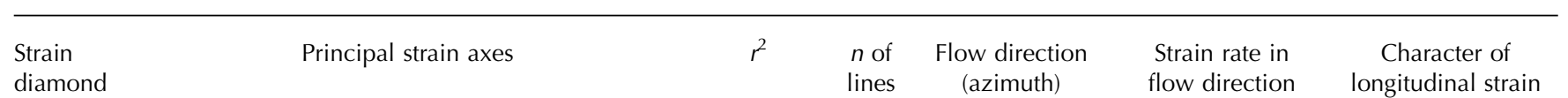

diamond

Maximum (azimuth) Minimum (azimuth)

(strain rate $10^{-4} \mathrm{a}^{-1}$ ) (strain rate $10^{-4} \mathrm{a}^{-1}$ )

$10^{-4} \mathrm{a}^{-1}$

\begin{tabular}{|c|c|c|c|c|c|c|c|}
\hline \multirow[t]{2}{*}{ A } & 095 (088/103) & 005 (358/013) & 0.821 & 8 & 073 & +0.1 & Extending \\
\hline & $+1.6(+1.1 /+2.2)$ & $-2.5(-3.4-1.4)$ & & & & $(+0.1 /+0.2)$ & \\
\hline \multirow[t]{2}{*}{ B } & $086(078 / 094)$ & $176(168 / 184)$ & 0.838 & 8 & 073 & +3.0 & Extending \\
\hline & $+3.2(+2.6 /+4.0)$ & $-0.7(-1.4 / 0.0)$ & & & & $(+2.3 /+3.7)$ & \\
\hline \multirow[t]{2}{*}{ C } & $167(114 / 215)$ & $077(024 / 125)$ & 0.229 & 8 & 076 & +0.4 & Extending? \\
\hline & $+1.1(+0.5 /+1.9)$ & $+0.3(-0.2 /+0.7)$ & & & & $(-0.1 /+0.8)$ & \\
\hline \multirow[t]{2}{*}{$\mathrm{D}$} & $112(094 / 130)$ & $022(004 / 40)$ & 0.564 & 8 & 062 & -0.8 & Compressing \\
\hline & $+0.3(-0.4 /+0.9)$ & $-1.5(-2.2 /-0.8)$ & & & & $(-0.1 /-1.4)$ & \\
\hline \multirow[t]{2}{*}{$E$} & $116(111 / 122)$ & $026(021 / 032)$ & 0.940 & 8 & 066 & -2.3 & Compressing \\
\hline & $+1.6(+0.9 /+2.4)$ & $-4.8(-5.6 /-4.2)$ & & & & $(-1.5 /-3.1)$ & \\
\hline \multirow[t]{2}{*}{$\mathrm{F}$} & $158(151 / 166)$ & $068(061 / 076)$ & 0.889 & 8 & 070 & -1.3 & Compressing \\
\hline & $+3.3(+2.6 /+4.1)$ & $-1.3(-2.0 /-0.7)$ & & & & $(-0.7 /-2.0)$ & \\
\hline \multirow[t]{2}{*}{ G } & 003 (358/009) & $093(88 / 99)$ & 0.937 & 5 & 047 & +3.1 & Extending \\
\hline & $+6.5(+5.5 /+7.6)$ & $-0.9(-1.9 /-0.1)$ & & & & $(+2.3 /+3.9)$ & \\
\hline \multirow[t]{2}{*}{$\mathrm{H}$} & $106(037 / 172)$ & $016(307 / 082)$ & 0.082 & 8 & 051 & +0.8 & Extending? \\
\hline & $+2.3(+0.6 /+6.0)$ & $+0.1(-3.6 /+1.9)$ & & & & $(-2.3 /+4.0)$ & \\
\hline 1 & $+2.6(-1.4 /+7.1)$ & $-6.6(-10.4 /-3.1)$ & & & & $(-10.0 /-2.5)$ & \\
\hline \multirow[t]{2}{*}{$J$} & $083(071 / 094)$ & $173(161 / 184)$ & 0.790 & 8 & 055 & +3.2 & Extending? \\
\hline & $+8.2(+3.7 /+13.3)$ & $-12.1(-16.3 /-8.0)$ & & & & $(-1.2 /+7.8)$ & \\
\hline \multirow[t]{2}{*}{ K } & $172(153 / 190)$ & $082(063 / 100)$ & 0.559 & 8 & 065 & -4.9 & Compressing \\
\hline & $+4.7(+0.5 /+8.9)$ & $-5.9(-10.0 /-2.4)$ & & & & $(-8.8 /-1.1)$ & \\
\hline \multirow[t]{2}{*}{$\mathrm{L}$} & $133(085 / 182)$ & $043(355 / 092)$ & 0.239 & 8 & 061 & -5.0 & Compressing \\
\hline & $-3.1(-4.2 /-1.4)$ & $-5.2(-7.0 /-3.9)$ & & & & $(-6.5 /-3.5)$ & \\
\hline
\end{tabular}

Notes: $r^{2}$ is for the fit of the calculated strain ellipse to the linear strain data at each diamond. '?' indicates that the character of longitudinal strain at a diamond is established at $<95 \%$ certainty.

For six diamonds (A, B, E, F, G, J) the calculations yielded a close fit to measured data $\left(r^{2} \geq 0.790\right)$, for three (D, I, K) there was a moderately good fit $\left(0.470<r^{2}<0.560\right)$, and for the remaining three $(C, H, L)$ the fit was poor $\left(r^{2}<0.240\right)$. In the first group, uncertainty in orientation of calculated principal strain axes is generally less than $10^{\circ}$, in the second group it is about $\pm 20^{\circ}$ and in the final group it is $\pm 50^{\circ}$ or more. The poorness of fit in the latter group could reflect either inhomogeneity of strain across these diamonds, or tilting or sliding of one or more of the marked clasts at a diamond. While the poor fit at these diamonds precludes the use of these best-fit ellipse result for assessing the orientation of principal strain axes and the strain rate along these axes, data from the diamonds are of some use, indicating, for example, that at diamond $\mathrm{L}$, shortening is occurring in all directions, including the flow direction.

Strain parameters are plotted by diamond location in Figure 6. Figure 6a shows the calculated orientations of principal strain axes and their sense of strain (extension or shortening). Lengths of the arrows indicate the relative rates of strain along the principal axes within, but not between, individual diamonds. Strain axes from the three diamonds that yielded poor strain ellipse fits are not plotted. At a first glance, the pattern of principal strain orientations in Figure 6a is complex and it is difficult to deduce an overall pattern. The high $r^{2}$ values for the nine diamonds plotted indicate that this complexity is not an artifact of nonhomogeneous strain, or tilting or sliding of measured clasts, but reflects variations in local strain field across the rock glacier. Much, but not all, of the variation is explicable in terms of patterns of longitudinal strain and shearing along the margins of the rock glacier as discussed below. Figure $6 b$ shows the character of longitudinal strain in the flow direction ('extending flow' or 'compressing flow') at each diamond. Lower-case letters indicate $<95 \%$ certainty on the character of the longitudinal flow regime at a diamond. A clear pattern of longitudinal strain is evident, with an alternation of compressing and extending flow regimes down-glacier. Figure $6 \mathrm{c}$ and $\mathrm{d}$ show the maximum measured strain rate and the maximum strain rate determined from the best-fit ellipse calculations respectively for each diamond, both in units of $10^{-4} \mathrm{a}^{-1}$. The three diamonds yielding poor fits are not plotted in Figure $6 \mathrm{~d}$. In both figures, maximum strain rates occur at diamond J, along the north side of the rock glacier, and strain rates are higher in the upper portion of the rock glacier than in the lower portion. Figure 6e shows the per cent change in measured strain rates between 1985-92 and 1992-99. Although strain rates decreased by about $20 \%$ overall (Table 1 ), with rates decreasing by up to $57 \%$ at individual diamonds, along the southern margin of the rock glacier strain rates increased by $9-18 \%$.

Down-valley movement profiles along the three surveyed transects are shown in Figure 6f, and calculated downglacier velocities for the three lines are given in Table 3. Over the 15 year survey interval (AD 1985-2000) downglacier flow averaged only $4-7 \mathrm{~cm} \mathrm{a}^{-1}$ along the three lines, with somewhat higher rates $\left(6-10 \mathrm{~cm} \mathrm{a}^{-1}\right)$ near the center 
a

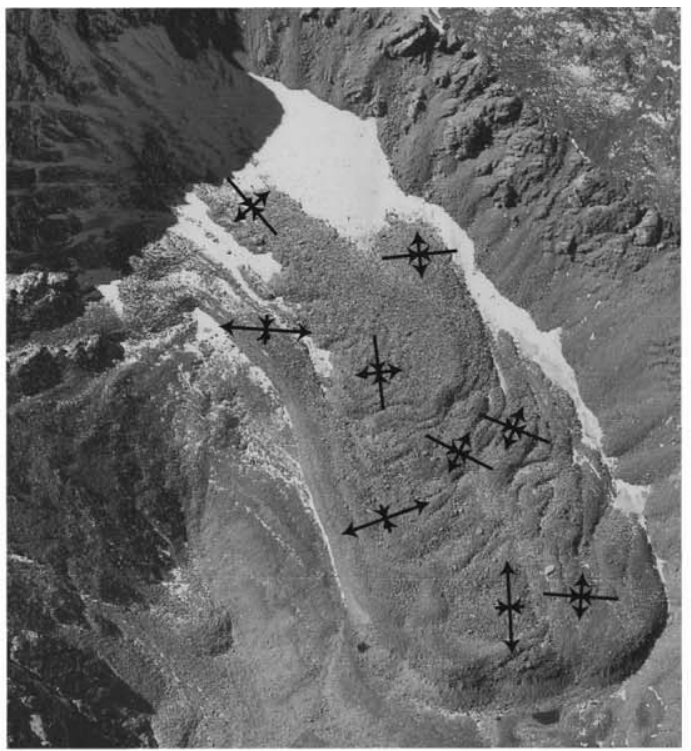

C

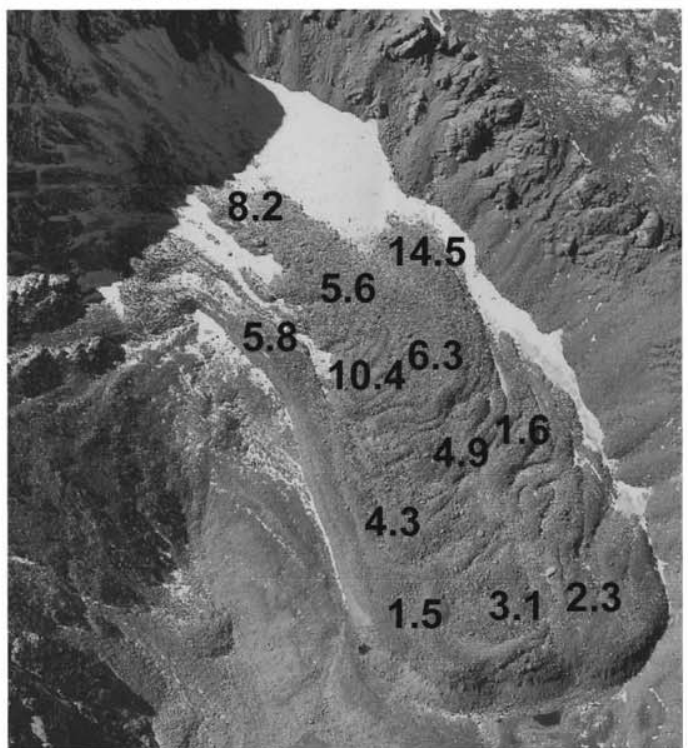

e

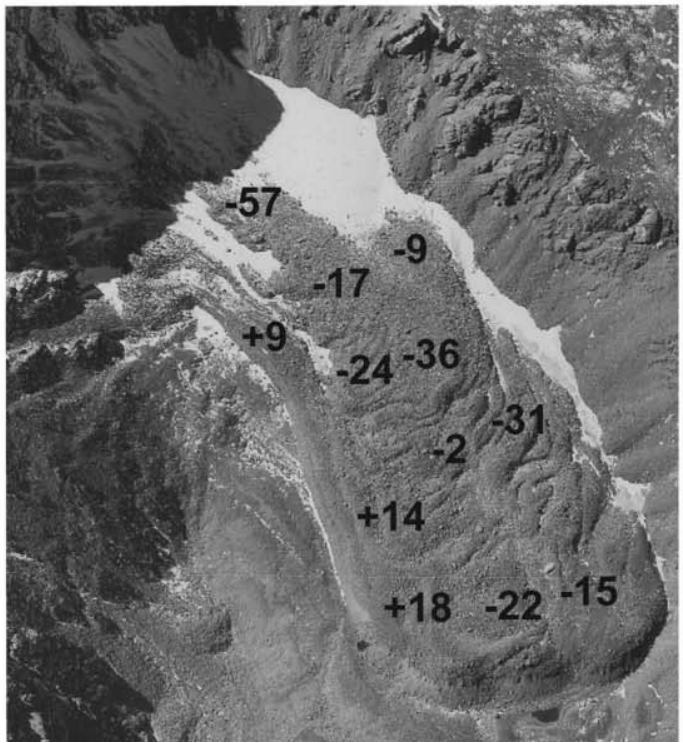

b

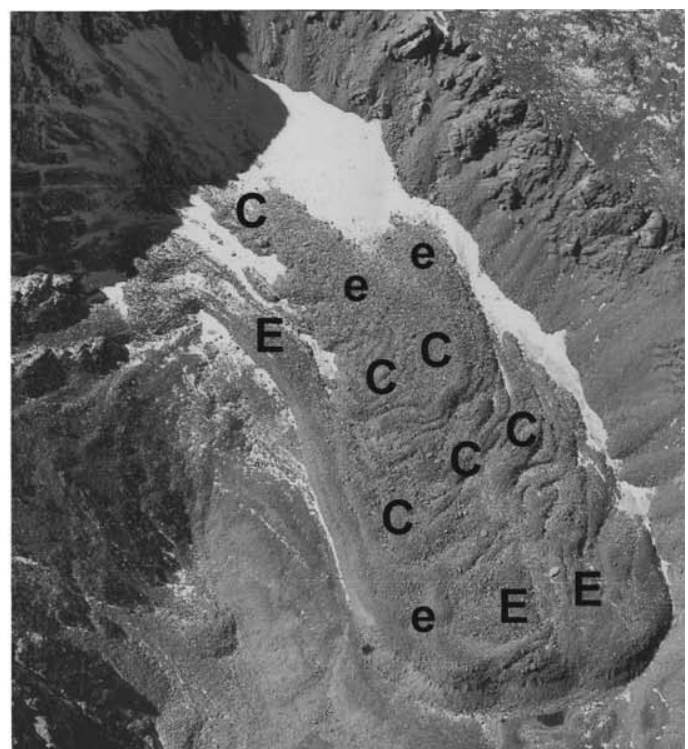

d

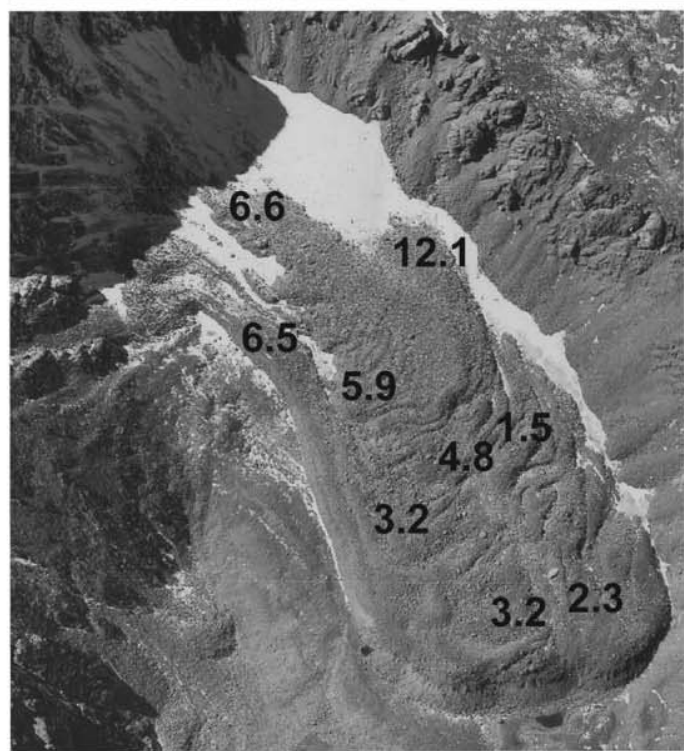

f

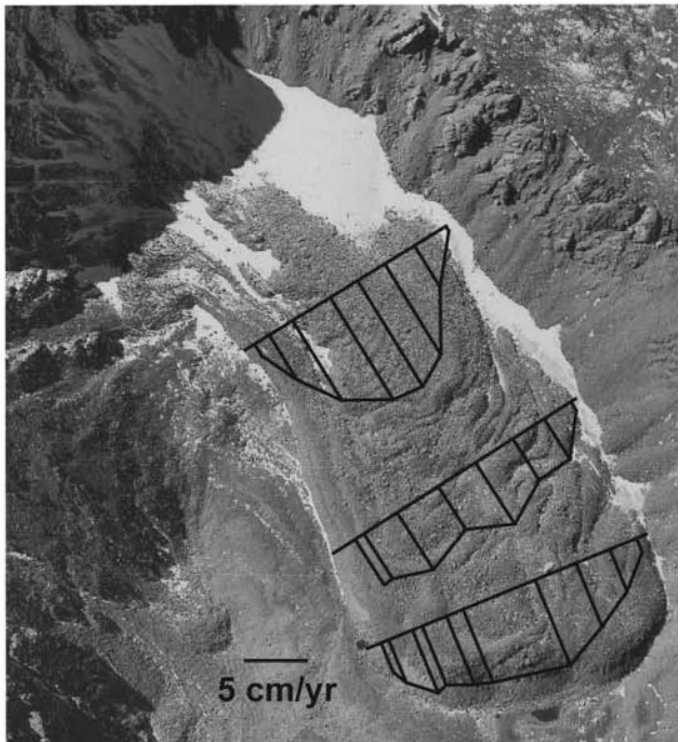

Fig. 6. Measured and calculated strain parameters including (a) calculated principal strain axis orientations and relative strain rates along the principal axes; (b) calculated longitudinal flow regime, extending (E) or compressing (C), with lower-case letters indicating certainties of $<95 \%$ in flow regime determination; (c) maximum measured strain rate $\left(\times 10^{-4} \mathrm{a}^{-1}\right)$; (d) maximum calculated strain rate $\left(\times 10^{-4} \mathrm{a}^{-1}\right)$; (e) per cent change in strain rate between the first 7 years (1985-92) and the second 7 years (1992-99) of the study; and (f) measured mean velocities (1985-2000) along three transect lines. 
Table 3. Down-valley velocities across three surveyed transects

\begin{tabular}{lccc}
\hline & \multicolumn{3}{c}{$\begin{array}{c}\text { Mean velocity } \\
1991-2000\end{array}$} \\
& $\begin{array}{c}1985-91 \\
\mathrm{~cm} \mathrm{a}^{-1}\end{array}$ & $\begin{array}{c}1985-2000 \\
\mathrm{~cm} \mathrm{a}^{-1}\end{array}$ \\
\hline Upper transect & 7.9 & 5.9 & 6.7 \\
Middle transect & 3.5 & 5.2 & 4.5 \\
Lower transect & 5.2 & 5.6 & 5.4 \\
\hline
\end{tabular}

Notes: See Figure $6 f$ for location of transects. All points on the middle transect are located down-glacier of the two lobe fronts shown in Figures 2 and 3 .

line. These rates are near the lower end of the range of rates reported elsewhere for active rock glaciers (Vitek and Giardino, 1987; Barsch, 1996; Frauenfelder and others, 2003). Measured velocities on the upper portion of the rock glacier are $25-50 \%$ higher than those on the lower portion, and a reduction of about $2 \mathrm{~cm} \mathrm{a}^{-1}$ takes place down-glacier. The difference in flow rate between the upper and lower portion of the rock glacier appears to have decreased through the survey period, due mainly to a slowing of the upper portion of the rock glacier.

\section{DISCUSSION}

\section{Patterns of strain}

The principal strain orientations (Fig. 6a) and the resultant character of longitudinal strain (Fig. 6b) yield information on the first-order controls on rock glacier surface strain. The overall pattern of longitudinal strain indicates a strong control by changes in surface slope, with down-valley steepening resulting in extending flow, and down-valley reduction in slope resulting in compressing flow. Gentle rolls in the surface profile of the rock glacier (Fig. 3) are reflected in changes in longitudinal strain. Flow is compressing in the upper portion of the rock glacier (diamond I) where steep talus above gives way to the much flatter rock glacier surface, and then becomes extending somewhat further down-glacier (diamonds G, $\mathrm{H}$ and J) where gradient increases again. The central portion of the rock glacier is a broad zone of compressing flow. This compression is related to another shallowing of the surface slope, particularly near diamonds D-F. Near the terminus, where surface gradient again increases, another region of extending flow (diamonds A-C) is evident. Kääb and others (1998) previously noted a strong control on rock glacier flow regime exerted by changes in surface slope. Compressing flow at diamonds $\mathrm{K}$ and $L$ appears to be related less to a change in slope than to the presence of an impinging up-glacier lobe (Fig. 3). While there is no significant slope change near these two diamonds, they are located near the lower end of the upper of two apparent faster-moving lobes that are impinging on the lower portion of the rock glacier. This situation appears to have generated compressional conditions in the frontal portion of the lobes.

Shear strain reflecting low flow velocities along the sides of the rock glacier modifies the overall strain pattern driven by alternations of longitudinal extension and shortening (Fig. 6a). Shear strain at the rock glacier margins is particularly evident at diamonds A, D, G and J, where the maximum (extensional) principal strain axes are 'rotated inward' $22-50^{\circ}$ from the flow direction and side of the rock glacier. Of the diamonds near the margins, only diamond $F$ does not show evidence of such shear. Down-valley flow measurements (Fig. 6f) also indicate that there is little shear at this site.

\section{Strain rates}

Strain rates found in this study were at the low end of the range of rates determined photogrammetrically for Swiss rock glaciers (Haeberli and others, 1979; Kääb and others, 1997, 1998). This is not surprising in view of the low overall flow velocity of Spruce Creek rock glacier, which is similarly at the low end of the range determined for the Swiss rock glaciers. Relatively high strain rates at the rock glacier are associated with either overall higher velocity or localized large differential velocities. On the upper portion of the rock glacier, 15 year averaged velocities (Table 3) are about $35 \%$ higher than on the lower part of the rock glacier, and maximum strain rates (Fig. 6c and d) are 2-3 times as high. On the lower part of the rock glacier, highest strain rates occur, not where overall velocities are highest, but where the faster-moving upper portion of the rock glacier is impinging on the lower portion (diamonds $E$ and $\mathrm{F}$ ).

The overall decrease in strain rate during the second half of the survey period was associated with a slowing of the upper part of the rock glacier and a decrease in the rate of differential movement between the upper and lower portions of the rock glacier (Table 3). It is unclear why the reduction in strain rate was limited to the central and northern portions of the rock glacier, while strain rates along the southern margin increased.

There are several possible explanations for the low overall flow velocities and strain rates.

1. Low rates may reflect the low slope of the rock glacier, an explanation consistent with the observation that longitudinal strain state at the rock glacier is closely related to slope variations. Frauenfelder and others (2003) have argued, however, that there is little correlation between average slope of a rock glacier and its surface velocity.

2. Frauenfelder and others (2003) suggest that temperature may be the dominant control on flow rate. Following Hoelzle and others (1998), they suggest that internal ('ground') temperature is the key control, but their data show a strong relationship between mean annual air temperature (MAAT) at the rock glacier terminus and flow velocity, with all rock glaciers with MAAT $<-3^{\circ} \mathrm{C}$ having mean flow velocities $\leq 10 \mathrm{~cm} \mathrm{a}^{-1}$. Low flow velocities at Spruce Creek rock glacier, where MAAT is approximately $-4^{\circ} \mathrm{C}$, are consistent with this observation.

3. Low flow rates may reflect the internal structure, if deformation is limited to an ice-rich upper portion of the rock glacier above debris-rich, non-deforming material (Haeberli and others, 1998). In the absence of information on the internal structure of Spruce Creek rock glacier it is not possible to evaluate this possibility.

4. Low rates may reflect recent stagnation of the rock glacier. Photogrammetric and lichen measurements indicate that flow has slowed by a factor of about five during the last century, possibly as a result of ice loss due 
Table 4. Relationship between transverse ridges and shortening strain. Numbers in parentheses are $95 \%$ certainty ranges

\begin{tabular}{|c|c|c|c|c|c|}
\hline \multirow[t]{2}{*}{$\begin{array}{l}\text { Strain } \\
\text { diamond }\end{array}$} & \multirow[t]{2}{*}{$\begin{array}{l}\text { Approximate transverse } \\
\text { ridge orientation } \\
\text { (azimuth) }\end{array}$} & \multirow[t]{2}{*}{$\begin{array}{l}\text { Approximate normal to } \\
\text { transverse ridge } \\
\text { (azimuth) }\end{array}$} & \multirow[t]{2}{*}{$\begin{array}{l}\text { Calculated shortening } \\
\text { direction (azimuth) }\end{array}$} & \multirow{2}{*}{$\begin{array}{l}\text { Maximum calculated } \\
\text { shortening rate } \\
\qquad 10^{-4} \mathrm{a}^{-1}\end{array}$} & \multirow{2}{*}{$\begin{array}{l}\text { Calculated differential } \\
\text { strain rate } \\
\qquad 10^{-4} \mathrm{a}^{-1}\end{array}$} \\
\hline & & & & & \\
\hline $\mathrm{D}$ & 307 & 037 & $022(004-040)$ & -1.5 & 1.8 \\
\hline $\mathrm{E}$ & 319 & 049 & $026(021-032)$ & -4.8 & 6.4 \\
\hline K & 329 & 059 & $082(063-100)$ & -5.9 & 10.6 \\
\hline \multirow{2}{*}{\multicolumn{4}{|c|}{$\begin{array}{l}\text { Range of values for strain diamonds undergoing longitudinal shortening with well-developed } \\
\text { transverse ridges (diamonds D, E, K) } \\
\text { Range of values for strain diamonds undergoing longitudinal shortening without } \\
\text { well-developed transverse ridges (diamonds F, I, L) }\end{array}$}} & -1.5 to -5.9 & $1.8-10.6$ \\
\hline & & & & -1.3 to -6.6 & $2.1-9.2$ \\
\hline
\end{tabular}

Note: Calculated differential strain rate is the difference between calculated strain rates along the two axes of the strain ellipse for each diamond.

to post-Little Ice Age temperature increase (Leonard and others, unpublished information).

Based on available data, it is not possible to determine what factor, or what combination of factors, is responsible for the current low flow and strain rates.

\section{Transverse ridges}

It has long been believed that transverse ridge and furrow systems on rock glaciers are products of compressing flow, generally related to down-glacier decreases in surface slope (Wahrhaftig and Cox, 1959; Loewenherz and others, 1989). Steel-tape measurements by White (1987) across a series of transverse ridges at Arapaho rock glacier, Colorado, confirmed that longitudinal shortening was occurring across the ridges. Kääb and others (1998) also confirmed the association of transverse ridges with compressing flow and decreased surface slope at Murtèl rock glacier, Switzerland. However, they also noted that the relationship between compression and transverse ridge development was not simple and that up-glacier areas of compressing flow did not exhibit transverse ridges.

Data from Spruce Creek confirm both the general association of transverse ridges with slope decrease and compressing flow, and the lack of a one-to-one correlation. Transverse ridge/furrow systems are well developed only in the middle portion of the rock glacier (Fig. 2) near strain diamonds D, E and L, an area of strongly compressional flow where (1) there is a significant down-glacier reduction in slope and (2) the more rapidly flowing upper portion of the rock glacier impinges on the slower lower portion. Where transverse ridges are well developed, they are approximately perpendicular to the calculated direction of greatest shortening (Table 4). Transverse ridges are absent or poorly developed in areas of extending flow, but also in the area of compressing flow at the head of the rock glacier (near diamond I) and in some mid-rock-glacier areas where flow is strongly compressional (near diamonds $\mathrm{F}$ and $\mathrm{L}$ ). It is unclear why transverse ridges are well formed in some areas of compressing flow but not in others. The difference does not appear to be related to either rate of longitudinal shortening or the differential strain rate (Table 4). Occurrence of transverse ridges is also not related purely to position down-glacier, which might reflect a progressive downglacier increase in total magnitude of shortening (Kääb and others, 1998).

\section{CONCLUSIONS}

Patterns of strain at Spruce Creek rock glacier are related primarily to changes in surface slope, with longitudinal extension resulting from down-glacier increases in slope, and longitudinal shortening from down-glacier slope decrease. This pattern is modified by shear along the sides of the rock glacier. It is also complicated by the presence of two slightly faster-moving lobes in the upper section of the rock glacier that appear to be impinging on a slower-moving lower section, resulting in a broad middle zone of longitudinal shortening. Strain rates are relatively high in the upper, fastermoving portion of the rock glacier and in the mid-rockglacier zone of longitudinal shortening, and relatively low in the lower portion of the rock glacier. During the survey period, the velocity difference between the upper and lower portions of the rock glacier decreased, due primarily to a reduction of flow in the upper area, a change accompanied by an overall decrease in strain rate. This slowing of the upper portion of the rock glacier is consistent with a previously noted reduction of flow velocities since the mid-20th century (Leonard and others, unpublished information).

Analysis of strain in portions of the rock glacier with welldeveloped transverse ridges confirms the general association of such features with longitudinal shortening. However, as previously suggested by Kääb and others (1998), the relationship between longitudinal shortening and transverse ridge development is not simple, and in several areas of strong shortening, no transverse ridges have developed.

\section{ACKNOWLEDGEMENTS}

S. Janke got us started thinking about statistical analysis of strain measurements. L. Vierling produced surface profiles of the rock glacier, under the guidance of J. Messerich at the US Geological Survey photogrammetry laboratory in Denver, Colorado. W. Haeberli and B. Hubbard provided very helpful reviews of the manuscript. More than a dozen Colorado College undergraduate geology students assisted us in the field.

\section{REFERENCES}

Arenson, L., M. Hoelzle and S. Springman. 2002. Borehole deformation measurements and internal structure of some rock glaciers in Switzerland. Permafr. Periglac. Process., 13(2), 117-135. 
Arenson, L.U., S.M. Springman and P.G. Hawkins. 2003 a. Pressuremeter tests within an active rock glacier in the Swiss Alps. In Phillips, M., S.M. Springman and L.A. Arenson, eds. Permafrost: Proceedings of the 8th International Conference on Permafrost, 21-25 July 2003, Zürich, Switzerland. Lisse, Balkema, 33-38.

Arenson, L.U., N. Almasi and S.M. Springman. 2003b. Shearing response of ice-rich rock glacier material. In Phillips, M., S.M. Springman and L.A. Arenson, eds. Permafrost: Proceedings of the 8th International Conference on Permafrost, 21-25 July 2003, Zürich, Switzerland. Lisse, Balkema, 39-44.

Barsch, D. 1996. Rockglaciers: indicators for the present and former geoecology in high mountain environments. Berlin, etc., Springer-Verlag.

Barsch, D. and G. Hell. 1975. Photogrammetrische Bewegungsmessungen am Blockgletscher Murtèl I, Oberengadin, Schweizer Alpen. Z. Gletscherkd. Glazialgeol., 11(2), 111-142.

Benedict, J.B., R.J. Benedict and D. Sanville. 1986. Arapaho Rock Glacier, Front Range, Colorado, U.S.A.: a 25-year resurvey. Arct. Alp. Res., 18(3), 349-352.

Burden, R.L. and J.D. Faires. 2001. Numerical analysis. Seventh edition. Pacific Grove, CA, Brooks/Cole.

Frauenfelder, R. and A. Kääb. 2000. Towards a palaeoclimatic model of rock-glacier formation in the Swiss Alps. Ann. Glaciol., 31, 281-286.

Frauenfelder, R., W. Haeberli and M. Hoelzle. 2003. Rockglacier occurrence and related terrain parameters in a study area of the Eastern Swiss Alps. In Phillips, M., S.M. Springman and L.A. Arenson, eds. Permafrost: Proceedings of the 8th International Conference on Permafrost, 21-25 July 2003, Zürich, Switzerland. Lisse, Balkema, 253-258.

Good, P.I. 1999. Resampling methods: a practical guide to data analysis. Boston, MA, Birkhäuser.

Haeberli, W., L. King and A. Flotron. 1979. Surface movement and lichen-cover studies at the active rock glacier near the Grubengletscher, Wallis, Swiss Alps. Arct. Alp. Res., 11(4), 421-441.

Haeberli, W., M. Hoelzle, A. Kääb, F. Keller, D. Vonder Mühll and S. Wagner. 1998. Ten years after drilling through the permafrost of the active rock glacier Murtèl, eastern Swiss Alps: answered questions and new perspectives. In Lewkowicz, A.G. and M. Allard, eds. Proceedings of the 7th International Conference on Permafrost, 23-27 June 1998, Yellowknife, N.W.T., Canada. Laval, Université Laval. Centre d'Etudes Nordiques, 403-410.

Hoelzle, M., S. Wagner, A. Kääb and D. Vonder Mühll. 1998. Surface movement and internal deformation of ice-rock mixtures within rock glaciers in the Upper Engadin, Switzerland. In Lewkowicz, A.G. and M. Allard, eds. Proceedings of the 7th International Conference on Permafrost, 23-27 June 1998, Yellowknife, N.W.T., Canada. Laval, Université Laval. Centre d'Etudes Nordiques, 465-471.

Johnson, J.P., Jr and W.G. Nickling. 1979. Englacial temperature and deformation of a rock glacier in the Kluane Range, Yukon Territory, Canada. Can. J. Earth Sci., 16(12), 2275-2283.

Kääb, A. and M. Vollmer. 2000. Surface geometry, thickness changes, and flow fields on creeping mountain permafrost: automated extraction by digital image analysis. Permafr. Periglac. Process., 11(4), 315-326.

Kääb, A., W. Haeberli and G.H. Gudmundsson. 1997. Analysing the creep of mountain permafrost using high precision aerial photogrammetry: 25 years of monitoring Gruben rock glacier, Swiss Alps. Permafr. Periglac. Process., 8(4), 409-426.

Kääb, A., G.H. Gudmundsson and M. Hoelzle. 1998. Surface deformation of creeping mountain permafrost. Photogrammetric investigations on rock glacier Murtèl, Swiss Alps. In Lewkowicz, A.G. and M. Allard, eds. Proceedings of the 7th International Conference on Permafrost, 23-27 June 1998, Yellowknife, N.W.T., Canada. Laval, Université Laval. Centre d'Etudes Nordiques, 531-537.

Kääb, A., K. Isaksen, T. Eiken and H. Farbrot. 2002. Geometry and dynamics of two lobe-shaped rock glaciers in the permafrost of Svalbard. Norsk Geografisk Tidsskrift, 56(2), 152-160.

Kaufmann, V. and R. Ladstädter. 2003. Quantative analysis of rock glacier creep by means of digital photogrammetry using multitemporal aerial photographs: two case studies in the Austrian Alps. In Phillips, M., S.M. Springman and L.A. Arenson, eds. Permafrost: Proceedings of the 8th International Conference on Permafrost, 21-25 July 2003, Zürich, Switzerland. Lisse, Balkema, 525-530.

Kenyi, L.W. and V. Kaufmann. 2003. Measuring rock glacier surface deformation using SAR interferometry. In Phillips, M., S.M. Springman and L.A. Arenson, eds. Permafrost: Proceedings of the 8th International Conference on Permafrost, 21-25 July 2003, Zürich, Switzerland. Lisse, Balkema, 537-541.

Konrad, S.K., N.F. Humphrey, E.J. Steig, D.H. Clark, N. Potter, Jr and W.T. Pfeffer. 1999. Rock glacier dynamics and paleoclimatic implications. Geology, 27(12), 1131-1134.

Loewenherz, D.S., C.J. Lawrence and R.L. Weaver. 1989. On the development of transverse ridges on rock glaciers. J. Glaciol., 35(121), 383-391.

Messerli, B. and M. Zurbuchen. 1968. Blockgletscher in Weissmies und Aletsch und ihre photogrammetrische Kartierung. Die Alpen, Zeitschrift, Schweizer Alpen-Clubs, 44(3), 45-78.

Nye, J.F. 1959. A method of determining the strain-rate tensor at the surface of a glacier. J. Glaciol., 3(25), 409-419.

Paterson, W.S.B. 1994. The physics of glaciers. Third edition. Oxford, etc., Elsevier.

Potter, N., Jr. 1972. Ice-cored rock glacier, Galena Creek, northern Absaroka Mountains, Wyoming. Geol. Soc. Am. Bull., 83(10), 3025-3057.

Rignot, E., B. Hallet and A. Fountain. 2002. Rock glacier surface motion in Beacon Valley, Antarctica, from synthetic-aperture radar interferometry. Geophys. Res. Lett., 29(12), 1607. (10.1029/2001GL013494.)

Tweto, O. 1974. Geological map of Mount Lincoln 15 minute quadrangle, Eagle, Lake, Park and Summit Counties, Colorado. (1:62,500.) Miscellaneous Field Studies Map No. MF-556, US Geological Survey.

Vitek, J.D. and J.R. Giardino. 1987. Rock glaciers: a review of the knowledge base. In Giardino, J.R., J.F. Shroder, Jr and J.D. Vitek, eds. Rock glaciers. Winchester, MA, Allen and Unwin, 1-26.

Wagner, S. 1992. Creep of Alpine permafrost investigated on the Murtèl rock glacier. Permafr. Periglac. Process., 3(2), 157-162.

Wahrhaftig, C. and A. Cox. 1959. Rock glaciers in the Alaska Range. Geol. Soc. Am. Bull., 70(4), 383-436.

White, S.E. 1971. Rock glacier studies in the Colorado Front Range, 1961 to 1968. Arct. Alp. Res., 3(1), 43-64.

White, S.E. 1987. Differential movement across transverse ridges on Arapaho Rock Glacier, Colorado Front Range, U.S.A. In Giardino, J.R., J.F. Shroder, Jr and J.D. Vitek, eds. Rock glaciers. Winchester, MA, Allen and Unwin, 145-149. 